\title{
Production constraints of smallholder pig farms in agro-ecological zones of
}

\author{
Mpumalanga, South Africa
}

\section{Priscilla Munzhelele ${ }^{1,2}$, James Oguttu ${ }^{2}$, Olubunmi G. Fasanmi ${ }^{3,4} \&$ Folorunso O. Fasina $^{5 \#}$}

\begin{abstract}
${ }^{1}$ Nooitgedacht Research Station, Animal Research, Non-ruminant Sub-directorate, Department of Agriculture, Rural Development, Land Administration and Environmental Affairs.
\end{abstract}
${ }^{2}$ Department of Agriculture and Animal Health, College of Agriculture and Environmental Sciences, University of South Africa
${ }^{3}$ Department of Production Animal Studies, Faculty of Veterinary Science, University of Pretoria, Onderstepoort 0110, South Africa
${ }^{4}$ Department of Animal Health, Federal College of Animal Health and Production Technology, Ibadan, Nigeria
${ }^{5}$ Department of Veterinary Tropical Diseases, Faculty of Veterinary Science, University of Pretoria, Onderstepoort 0110, South Africa

${ }^{\#}$ Corresponding author: Prof. Fasina Folorunso Oludayo, Department of Veterinary Tropical Diseases, Faculty of Veterinary Science, University of Pretoria, Onderstepoort 0110, South Africa. Telephone: +27 12529 8069; E-mail: daydupe2003@yahoo.co.uk 


\begin{abstract}
South African pig sector is a contributor to the agricultural industry. A study was conducted to identify the production constraints and compare the management practices in smallholder pig farms in Mpumalanga, South Africa. A total of 220 selected smallholder pig farmers were interviewed. Smallholder pig farming was predominated by male (64\%), age above 50 years (54\%), black Africans (98.6\%) and three-quarters of the smallholder farmers were poor to just below average. Majority (80\%) have no pig husbandry training, while only $33 \%$ received assistance from government's Agricultural Department. In terms of stock, mixed breeds (89\%) from exotic pigs were mostly kept and majority (87\%) of the farmers kept $\leq 10$ sows in their herds. Many farmers (75\%) engaged in risky behaviour of buying auctioned-sourced boars, free-range boars and untested boars from neighbours and relatives. Few (17\%) farmers practiced vaccination and only $10 \%$ kept farm records. Majority of the responses on preweaning mortality (50\%) and post-weaning mortality (90\%) were within acceptable range of $1-10 \%$ and $1-5 \%$ mortality rates respectively. The lead causes of mortality were weak piglets and crushing (46\%), diarrhoea (27\%), poor management knowledge (19\%) and malnutrition (16\%). Agricultural training and government incentives will facilitate improved productivity in smallholder pig farming.
\end{abstract}

Keywords: Pre-weaning mortality; diseases; nutrition; smallholder pig farm. 


\section{Introduction}

Livestock industry is a major contributor to the national agricultural economy in South Africa. It contributes approximately $48 \%$ of agricultural outputs and $85 \%$ of the meat required in South Africa (DAFF, 2012a). Specifically, the South African pork industry contributes $2.15 \%$ to the primary agricultural sectors and Mpumalanga Province is ranked sixth in terms of the national gross domestic products (Boettiger, 2000). Whereas Madzimure et al. (2013) have previously determined some of the potentials associated with indigenous pigs in South Africa, other workers have highlighted some factors including genetics, housing, economics of scale, investment costs, nutrition, marketing, environmental issues, poor biosecurity and land tenure systems as major limitations to optimum productivity in pig production (Boettiger, 2000; SPAHAW, 2007; Oladele et al. 2013; Mokoele, et al. 2014). To date, no specific assessment has been conducted to evaluate the effect of different agro-ecologic and eco-climatic conditions of South Africa on pig management and productivity.

Mpumalanga province covers a total land area of $76,495 \mathrm{~km}^{2}(\approx 6.3 \%)$ of the total land areas of South Africa and is roughly divided into three distinct agro- ecological zones: the Highveld, the Lowveld and the Midveld. Each of the veld types are characterised by a set of climatic conditions and vegetation biomes (Acocks, 1988). The Highveld is characterised primarily with sour-veld (open countryside with grasses, bushes or shrubs) due to high rainfall and relatively lower temperature compared with those of the sweet-veld regions. The climate varies from moderate in summer $\left(25-27^{\circ} \mathrm{C}\right)$ to relatively cold winter with heavy frost when the environmental temperature drops below zero (Supplementary material A). The soil typically has high $\mathrm{pH}$ and rainfall varies from 601 to $900 \mathrm{~mm} / \mathrm{annum}$ (Engelbrecht et al. 2004). 
The Midveld rainfall varies from $501-750 \mathrm{~mm} / \mathrm{annum}$ and it is characterized by semisweetveld vegetation type. Acocks (1988), had previously described the climate and vegetations associated with the Midveld. The Lowveld presents with warm moist climate and an annual rainfall of between $601-1300 \mathrm{~mm} /$ annum (Supplementary material A). The province shares international boundaries with Mozambique and Swaziland; and it is also contiguous to Limpopo, Gauteng, KwaZulu-Natal and the Free State Provinces in South Africa. In view of the extensive shared borders, the province has high risk of trans-boundary diseases that threatens its animal resources, food security, affects local and international trade and the livelihood of rural communities (Otte et al. 2004). In addition, because the province also shares part of its territories with the Kruger National Park, where certain trans-boundary diseases (including but not limited to foot-and-mouth disease in buffaloes and African swine fever in warthogs) are endemic in the wild populations, the risks of contracting infectious diseases by the domestic animals is significantly increased. In view of the above, good farm and management practices as well as excellent bio-security protocols are needed for pig farming in this province. Specifically, in the northern part of the Province, agricultural authorities must first assess a pig farm for compliance before an approval can be granted (DAFF, 2012b).

We conducted a survey among smallholder pig farmers in the three agro-ecological zones of Mpumalanga, South Africa to evaluate limitations to production, assess the predisposing factors to pig diseases and determine possible areas of interventions at the smallholder levels. 


\section{Materials and Methods}

\section{Study area}

The project was carried out with the research and ethics approval number: 2013/CAES/140 of the University of South Africa. Mpumalanga Province, South Africa $\left(26.0000^{\circ} \mathrm{S}, 30.0000^{\circ} \mathrm{E}\right)$ consist of a human population of 4.04 million (2013 estimates) and a relatively large pig farming population (STATSA, 2013). The province accounts for $8 \%$ of the commercial pigs in South Africa and only $4.12 \%$ of the total export from the country (DAFF, 2012a). However an unidentified numbers of smallholder farmers exist and based on the pig spatial distribution and marketing networks within the province, the study sites and subjects were randomly selected

\section{Data collection and management}

Data was collected through the use of a semi-structured and pre-tested questionnaire, checklist was used to evaluate the direct observations of the herd and facility, and photographic documentations were obtained where necessary. Extension officers and Animal Health Technicians from the Mpumalanga Department of Agriculture, Rural Development, Land Administration and Environmental Affairs (DARDLEA) were trained and used to administer the questionnaire. Inclusion criteria were (a) ownership of $\geq 1$ to $\leq 50$ pigs; (b) resident within the province and active in the smallholder industry. Although, the questionnaire was prepared in English, it was administered using native home languages (Zulu, IsiNdebele, Shangaan and Isiswati).

A total of 220 smallholder pig farmers were identified. All answers were recorded in English and entered into Microsoft Excel $2007^{\circledR}$ spreadsheet Filtered data was analysed using Stata v9 
(Statacorp., Texas, USA) and outputs were generated in frequency tables for farmers' and herd-related variables. Proportion of pre-weaning and post weaning mortality rates, and causes of mortality were produced in graphs. Associations between agricultural training, government's materials and or financial assistance, and the thirteen herd and farmer-related variables were analysed using multivariable logistic regression model.

\section{Results}

\section{Demographic profile of farmers who participated in the study}

Significantly more male respondents were engaged in small-scale pig farming than female in the study areas and more than half of the respondents $(\approx 54 \%)$ were older than 50 years (Table 1; Supplementary material B). A total of $78.7 \%$ were at least 40 years and above. In addition, majority of the smallholder pig farmers were classified as previously disadvantaged black South Africans (98.6\%) and over three quarters of all respondents were classified as poor to just below average (Table $1 ; P<0.01)$. Minority of the farmers $(<10 \%)$ have tertiary education and only $2.7 \%$ stayed in the urban centres while $97.3 \%$ live in rural or peri-urban locations. Family sizes differed significantly among the respondents (Table $1 ; P<0.01$ ), and only $19.6 \%$ and $33 \%$ of all respondents have received any form of agricultural training and financial or inputs assistance respectively (Table 1; Supplementary material B). 
Table 1: Farmers-related variables among the survey small-scale pig farmers, Mpumalanga $(\mathrm{n}=220)$

\begin{tabular}{|c|c|c|c|}
\hline Variables & Descriptors & $\begin{array}{c}\text { Mpumalanga }(n= \\
\text { 220) } \%\left(\mathbf{C I}_{95 \%}\right)\end{array}$ & P-value \\
\hline \multirow[t]{2}{*}{ Gender } & Male & $63.6(57.2 ; 70.0)$ & $<0.0001$ \\
\hline & Female & $36.4(30.0 ; 42.8)$ & \\
\hline \multirow[t]{5}{*}{ Age } & $<20$ years & $0.9(-0.4 ; 2.2)$ & $<0.01$ \\
\hline & 21-30 years & $7.3(3.8 ; 10.7)$ & \\
\hline & $31-40$ years & $13.2(8.7 ; 17.7)$ & \\
\hline & $41-50$ years & $24.6(18.8 ; 30.3)$ & \\
\hline & $>50$ years & $54.1(47.5 ; 60.7)$ & \\
\hline \multirow[t]{3}{*}{ Race } & Black & $98.6(97.1 ; 100.2)$ & $<0.0001$ \\
\hline & Coloured & $0.5(-0.4 ; 0.1)$ & \\
\hline & White & $0.9(-0.4 ; 21.7)$ & \\
\hline \multirow[t]{4}{*}{ Economic status } & Poor & $53.2(46.5 ; 59.8)$ & $<0.01$ \\
\hline & $\begin{array}{l}\text { Just below } \\
\text { average }\end{array}$ & $25.0(19.2 ; 30.8)$ & \\
\hline & Average & $20.9(15.5 ; 26.3)$ & \\
\hline & $\begin{array}{l}\text { Above } \\
\text { average }\end{array}$ & $0.9(-0.4 ; 2.2)$ & \\
\hline \multirow[t]{4}{*}{$\begin{array}{l}\text { Educational } \\
\text { qualification }\end{array}$} & $\begin{array}{l}\text { No formal } \\
\text { schooling }\end{array}$ & $18.2(13.1 ; 23.3)$ & $<0.01$ \\
\hline & Grade 1-11 & $54.1(47.5 ; 60.7)$ & \\
\hline & Grade 12 & $18.2(13.1 ; 23.3)$ & \\
\hline & Post-matric & $9.6(5.6 ; 13.5)$ & \\
\hline \multirow[t]{3}{*}{ Location } & Rural & $64.6(58.2 ; 70.9)$ & $<0.01$ \\
\hline & Urban & $2.7(0.6 ; 4.9)$ & \\
\hline & Peri-urban & $32.7(26.5 ; 39.0)$ & \\
\hline \multirow[t]{5}{*}{ Household size } & 1 & $1.4(-0.2 ; 2.9)$ & $<0.01$ \\
\hline & 2 & $8.2(4.5 ; 11.8)$ & \\
\hline & $3-5$ & $40.5(33.9 ; 47.0)$ & \\
\hline & $6-8$ & $40.5(33.9 ; 47.0)$ & \\
\hline & $>8$ & $9.6(5.6 ; 13.5)$ & \\
\hline \multirow{2}{*}{$\begin{array}{l}\text { Received } \\
\text { agricultural } \\
\text { training }\end{array}$} & No & $80.4(75.1 ; 85.7)$ & $<0.0001$ \\
\hline & Yes & $19.6(14.3 ; 24.9)$ & \\
\hline Received & No & $67.1(60.9 ; 73.4)$ & $<0.0001$ \\
\hline financial & Yes & $32.9(26.6 ; 39.2)$ & \\
\hline
\end{tabular}

assistance/inputs

Significant differences existed between or among the descriptors in each variables analysed..

\section{Pig management and constraints}

In terms of the breeds kept by smallholder farmers in Mpumalanga province, approximately $89 \%$ of the farmers used mixed breeds of exotic pigs (primarily Large White-Landrace crosses), and majority (87.3\%) of farmers had between $1-10$ sows in their herds (Table 2; Supplementary material $C ; P<0.01)$. In terms of animal husbandry, $75 \%$ of the farmers practiced the risky behaviour of using auction-sourced boars, free-range boars or untested boars from neighbours and relatives $(P<0.01)$. This practice has implications on disease spread (Table 2). Very few (13.6\%) of the respondents introduced the sows on oestrus to 
boars according to standard practice ( $1-3$ days) while $30 \%$ kept the sows in the boar house for upward of 1 month (Table 2; Supplementary material C).

Table 2: Herd-related variables among the survey small-scale pig farmers, Mpumalanga $(\mathrm{n}=220)$

\begin{tabular}{|c|c|c|c|}
\hline Variables & Descriptors & $\underset{\text { CI }_{05 \%}}{\operatorname{Mpumalanga}(\%)}$ & P-value \\
\hline \multirow{3}{*}{$\begin{array}{l}\text { Type of } \\
\text { breed kept }\end{array}$} & Kolbroek & $4.6(1.8 ; 7.3)$ & \multirow[t]{3}{*}{$<0.01$} \\
\hline & Exotic and their crosses & $89.1(84.9 ; 93.2)$ & \\
\hline & Mix of Kolbroek and exotic & $6.1(3.1 ; 9.6)$ & \\
\hline \multirow{4}{*}{$\begin{array}{l}\text { No of sow in } \\
\text { the herd }\end{array}$} & No breeding & $0.9(-0.4 ; 2.2)$ & \multirow[t]{4}{*}{$<0.01$} \\
\hline & $1-10$ sows & $87.3(82.8 ; 91.7)$ & \\
\hline & $11-20$ sows & $6.8(3.5 ; 10.2)$ & \\
\hline & $>20$ sows & $5(2.1 ; 7.9)$ & \\
\hline \multirow[t]{5}{*}{ Boar source } & Auction & $9.6(5.6 ; 13.5)$ & \multirow[t]{5}{*}{$<0.01$} \\
\hline & $\begin{array}{l}\text { Buy young and raise, select } \\
\text { from own boar }\end{array}$ & $13.2(8.7 ; 17.7)$ & \\
\hline & Free range & $1.4(-0.2 ; 2.9)$ & \\
\hline & Local project breeder & $16.8(11.8 ; 21.8)$ & \\
\hline & Neighbor, relative, mixed & $59.1(52.5 ; 65.6)$ & \\
\hline \multirow{2}{*}{$\begin{array}{l}\text { Boar and } \\
\text { sow stay } \\
\text { together } \\
\text { regularly }\end{array}$} & No & $60.6(54.0 ; 67.1)$ & \multirow[t]{2}{*}{$<0.0001$} \\
\hline & Yes & $39.5(32.9 ; 46.0)$ & \\
\hline \multirow{6}{*}{$\begin{array}{l}\text { Boar length } \\
\text { of stay with } \\
\text { sow during } \\
\text { mating }\end{array}$} & $1-3$ days & $13.6(8.9 ; 18.2)$ & \multirow[t]{6}{*}{$<0.0001$} \\
\hline & 1 week -1 month & $29.9(23.7 ; 36.1)$ & \\
\hline & 2 months -3 months & $1.9(0.4 ; 3.7)$ & \\
\hline & Continuous & $39.7(33.1 ; 46.3)$ & \\
\hline & Free range & $14.5(9.7 ; 19.2)$ & \\
\hline & Artificial insemination & $0.5(0.5 ; 1.4)$ & \\
\hline \multirow[t]{3}{*}{ Housing type } & Intensive & $18.3(13.1 ; 23.4)$ & \multirow[t]{3}{*}{$<0.01$} \\
\hline & Semi-intensive & $56.6(50.0 ; 63.2)$ & \\
\hline & Free range & $25.1(19.3 ; 30.9)$ & \\
\hline \multirow{5}{*}{$\begin{array}{l}\text { Number of } \\
\text { feeding per } \\
\text { day }\end{array}$} & Nil & $0.5(-0.5 ; 1.4)$ & \multirow[t]{5}{*}{$<0.01$} \\
\hline & Once & $26.7(20.9 ; 32.6)$ & \\
\hline & Twice & $66.4(60.0 ; 72.7)$ & \\
\hline & Thrice & $6.0(2.8 ; 9.2)$ & \\
\hline & Ad lib & $0.45(-0.45 ; 1.4)$ & \\
\hline \multirow{2}{*}{$\begin{array}{l}\text { Implement } \\
\text { vaccination }\end{array}$} & No & $83.0(78.0 ; 88.05)$ & \multirow[t]{2}{*}{$<0.0001$} \\
\hline & Yes & $17.0(12.0 ; 22.1)$ & \\
\hline Record & No & $90.4(86.4 ; 94.3)$ & \multirow[t]{2}{*}{$<0.0001$} \\
\hline keeping & Yes & $9.6(5.7 ; 13.6)$ & \\
\hline \multirow{3}{*}{$\begin{array}{l}\text { Number of } \\
\text { farrowing } \\
\text { per year }\end{array}$} & 1 & $12.4(8.0 ; 16.9)$ & \multirow[t]{3}{*}{$<0.01$} \\
\hline & 2 & $78.8(73.3 ; 84.3)$ & \\
\hline & Sometimes 3 & $8.76(4.97 ; 12.55)$ & \\
\hline \multirow{2}{*}{$\begin{array}{l}\text { Weighing } \\
\text { done before } \\
\text { sale }\end{array}$} & No & $\begin{array}{l}95.87(93.32 \\
98.53)\end{array}$ & \multirow[t]{2}{*}{$<0.0001$} \\
\hline & Yes & $4.13(1.47 ; 6.79)$ & \\
\hline
\end{tabular}

Whereas $25 \%$ practiced free range system, $75 \%$ used the intensive or semi-intensive management principles (Table 2; Supplementary material C). A total of $99.5 \%$ of the respondents fed their pigs once, twice or thrice while $0.5 \%$ fed either ad lib or not at all $(P<$ 0.0001; Supplementary material C). Eighty three percent (83\%) did not practice vaccination and $90 \%$ did not keep records. The numbers of farrowing per sow per year differed 
significantly amongst the respondents and $96 \%$ did not weigh their pigs for sale (Table 2; Supplementary material C).

Approximately half $(50 \%)$ of all pre-weaning mortalities were within the acceptable limit $(\leq$ $10 \%$ ) in the pig industry while similar percentages significantly exceeded the range. Some farms recorded pre-weaning mortalities in excess of 50\% (Figure 1a). Similarly, the majority $(\approx 90 \%)$ of the reported post-weaning mortalities were within the acceptable range of $1-5 \%$ (Figure 1b). The Lowveld had significantly higher abnormal pre-weaning mortality patterns compared with the Highveld and the Midveld regions (Figures 1a). The leading causes of preweaning mortalities were piglets born weak and crushing of piglets by sow and through overlay $=46 \%$, neonatal diseases including diarrhoea $=27.0 \%$, poor management knowledge $=19.4 \%$ and malnutrition of the piglets $=15.6 \%($ Table 3$)$.

Table 3. Major causes of piglet mortality reported among emerging small-scale pig farmers, Mpumalanga

\begin{tabular}{|c|c|c|c|}
\hline $\begin{array}{c}\text { Leading causes of neonatal } \\
\text { mortality }\end{array}$ & $\begin{array}{c}\text { Mpumalanga } \\
\text { Province }(n=211)\end{array}$ & Percentage & $\begin{array}{l}\text { 95\% Confidence } \\
\text { interval }\end{array}$ \\
\hline Veak piglets/crushing & 96 & 45.50 & 38.92; 52.24 \\
\hline Neonatal diseases & 57 & 27.01 & $21.47 ; 33.38$ \\
\hline edation & 21 & 9.95 & $6.60 ; 14.73$ \\
\hline nnibalism & 9 & 4.27 & $2.26 ; 7.91$ \\
\hline Ialnutrition & 33 & 15.64 & $11.36 ; 21.15$ \\
\hline ack of management knowledge & 41 & 19.43 & $14.66 ; 25.30$ \\
\hline Inknown causes & 9 & 4.27 & $2.26 ; 7.91$ \\
\hline ther reasons & 13 & 6.16 & $3.64 ; 10.25$ \\
\hline
\end{tabular}

Using the logistic regression models, the receipt of agricultural assistance (financial/inputs) from the government positively influence vaccination $(\mathrm{OR}=3.8 ; P=0.002)$, farrowing per year $(\mathrm{OR}=3.5 ; P=0.002)$ and economic statuses of the farmers $(\mathrm{OR}=1.8 ; P=0.004)$; however the odds of association between the animal housing types and receipt of government assistance was $0.5\left(P=0.0006\right.$; Hosmer-Lemeshow Goodness of fit probability $>\chi^{2}=0.98$; Table 4a). 


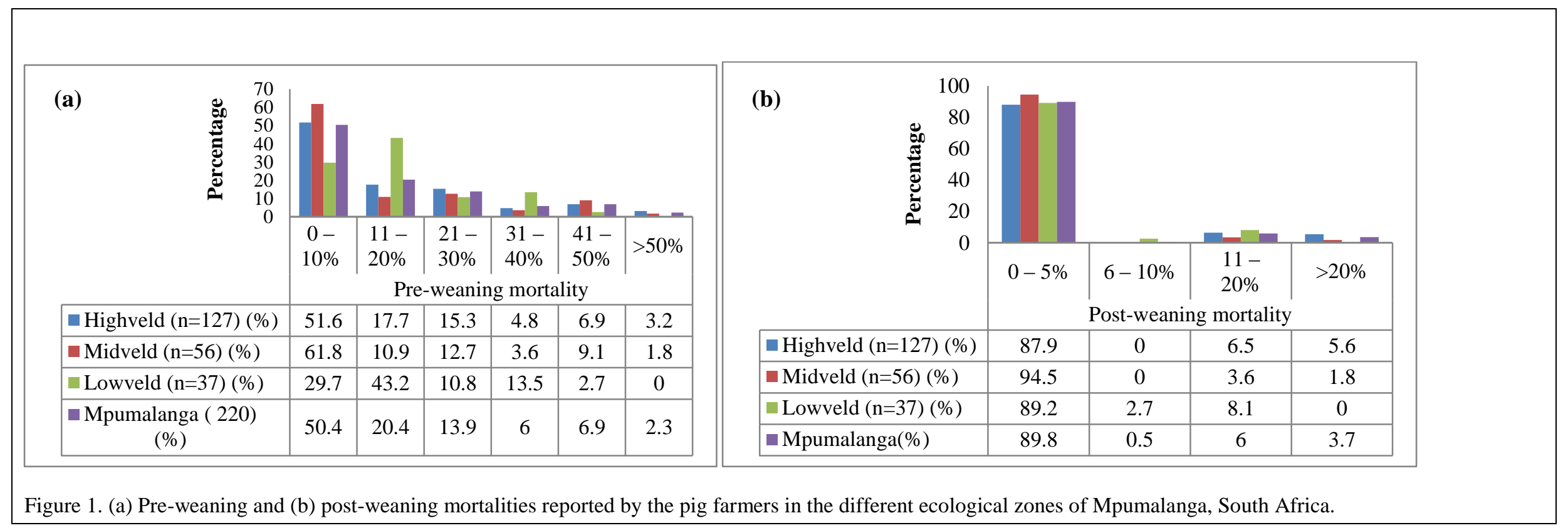


Table 4a. Association of receipt of government assistance with certain production variables

$\begin{array}{lrcc}\text { Variable } & \text { Odds Ratio } & 95 \% \text { Conf. Interval } & \text { P values } \\ \text { Vaccination } & 3.83 & 1.65 ; 8.85 & 0.002 \\ \text { Farrowing/year } & 3.50 & 1.57 ; 7.81 & 0.002 \\ \text { Housing types } & 0.48 & 0.29 ; 0.81 & 0.0006 \\ \text { Economic status } & 1.78 & 1.21 ; 2.62 & 0.004\end{array}$

$\chi^{2}=51.20 ;$ Goodness of fit $(\mathrm{GOF})$ Prob $>\chi^{2}=0.98 ;$ Akaike information criterion $(\mathrm{AIC})=232.37$

The model for the odds of association for agricultural training and other variables did not fit well since the Hosmer-Lemeshow Goodness of fit probability $>\chi^{2}=0.17$. However, there was a very good odds of associations between training and receipt of government assistance (OR $=10.4)$ and farrowing $/$ sow $/$ year $(\mathrm{OR}=4.1$; Table $4 \mathrm{~b})$

Table 4b. Association of training with certain production variables

$\begin{array}{lccc}\text { Variable } & \text { Odds Ratio } & 95 \% \text { Conf. Interval } & \text { P values } \\ \text { Ecological zones } & 0.58 & 0.36 ; 0.96 & 0.03 \\ \text { Farrowing/year } & 4.05 & 1.56 ; 10.51 & 0.004 \\ \text { Received assistance } & 10.35 & 4.50 ; 23.84 & <0.0001 \\ \chi^{2}=58.54 \text {; Goodness of fit }(\mathrm{GOF}) \text { Prob }>\chi^{2}=0.17 \text {; } & \text { Akaike information } & & \end{array}$

\section{Discussions and Conclusion}

The smallholder pig farmers' population structures in Mpumalanga resembled what has been described elsewhere in South Africa (Mokoele et al. 2014) and parts of Southern Africa (Nsoso et al. 2006). Pig production is labour-intensive and the ownership of land is a critical factor to successful pig production; these factors may affect the level of women participation in pig production because of the patrilineal system in rural and peri-urban South Africa. Women in parts of Southern Africa have been identified as primarily landless and are often denied the opportunity to participate in animal agriculture when compared with men (Cross and Hornby 2002; Kalabamu, 2006). Mokoele et al. (2014) have explained these limitations in the context of smallholder pig production in Limpopo, South Africa.

The proportion of individuals who received agricultural training was low (20\%). Insufficiency of specialised agricultural extension officers in the provision of pig husbandry 
training has been reported as a limitation in Botswana (Moreki and Mphinyane, 2011). Low percentage of trained pig farmers in Mpumalanga should be partially attributed to the reason why poor management knowledge was one of the leading causes of piglets deaths. We observed that larger family (greater than 6 individuals within the family) tend to go into pig husbandry; whether this was due to availability of enough persons as labour in the families or the basic need to supplement family income cannot be concluded on this report.

The majority of respondents (89\%) kept exotic and cross-bred pigs thereby enhancing the prospect of improving pig genetics and boosting agricultural potentials tremendously among smallholder farmers; Njuki et al. (2010) reported that the keeping of exotic and cross-bred enhance better growth rate and feed conversion efficiency. In Kenya, low genetic potential, malnourishment, high parasite prevalence and disease have been identified as reasons for low average daily weight gains (ADG) in smallholder pigs (Carter et al. 2013). While these are positive developments, they must however be supported with good management and biosecurity practices, training, vaccination and appropriate healthcare. In the current study, the animal management practices were poor, only $17 \%$ implemented vaccination, over $90 \%$ did not keep any record and $\approx 96 \%$ did not weigh their pigs for sale. These identified areas will need significant improvement and more interventions from the agricultural and veterinary authorities within the Province.

In this study, half of the farmers reported that pre-weaning mortality was within the acceptable range $(\leq 10)$. Elsewhere, pre-weaning mortality approached 5-8\% (Anonymous, 2015), 18\% in Australia (McCosker, 2014), 18 - 24\% in Central Lao PDR (Chittavong et al. 2012), 9.5 to $21 \%$ in Congo (Kambashi et al. 2014) and $22.6 \%$ in the USA (Li et al. 2010). Careful breeding programme, selection of boars with good litter scatter, efficient management and optimum feeding of pregnant sows (pre-lactation and during lactation), adequate vaccinations and assistance during farrowing as well as careful management of 
piglets and weaners will significantly reduce these unnecessary losses. While the postweaning mortality was largely within the limit, about $10 \%$ was associated mainly with diseases in weaned pigs. Appropriate measures previously mentioned above will correct or reduce these incidences (McCosker, 2014).

The leading causes of mortality identified in our study were piglets born weak/crushing, neonatal diseases, lack of management knowledge and malnutrition. Other studies have confirmed similar causes of avoidable neonatal deaths (NAHMS, 2000; Mokoele et al. 2014; Anonymous, 2015). Although the listed causes are discrete, we are aware that interactions of factors are responsible for majority of the causes of death in piglets and weanling pigs. However because weak piglets were crushed in over $50 \%$ of the cases and about $4.3 \%$ of the dead piglets were due to cannibalism in the farrowing house, we suggest that improved housing condition should be implemented and more attention should be paid to management in the farrowing pens to reduce incidences of pre-weaning mortality in piglets in smallholder farms.

The receipt of agricultural assistance from government and agricultural training positively influence other farm inputs and outputs. The government should explore how these identified inputs can be distributed to reach committed farmers within the province and such measure can be adopted nationally. Service providers should be engaged to facilitate agricultural training for smallholder pig farmers and distributions of inputs. Mokoele et al. (2014) have earlier advocated for the implementation of same measures in Limpopo Province.

Whereas the variables tested differed slightly between the three agro-ecological zones (Supplementary materials B \& C), clear differences existed in some variables. For example, while women formed a significant proportion of the Lowveld zone and the rural population was significantly higher, the Highveld had a significantly higher peri-urban population. 
Comparatively, the Lowveld had higher pre-weaning mortalities than the other agroecological zones (Table 1; Figure 1a). It is possible that the warmer moist condition of this agro-ecological zone as well as the comparative low level of education impact positively on the multiplication of neonatal pathogens' (e.g. Escherichia coli and Isospora suis) which in turn aggravated the situations of piglet mortalities in this zone.

In conclusion, smallholder farmers in Mpumalanga will benefit from carefully designed and restructured agricultural programmes that focus on training-linked agricultural inputs, more women participation, supply of improved breeds and oversight functions. In this study, we did not significantly associate differences in agro-ecological zones primarily with differences in farm outputs among smallholder farmers.

\section{Acknowledgements:}

We thank the Mpumalanga Department of Agriculture, Rural Development, Land Administration and Environmental Affairs for provision of access to the farmers. We are grateful to the farmers for cooperation, extension agricultural officers, animal researchers and animal health technicians for data collection through the administration of questionnaires. We thank the management of University of South Africa (Masters and Doctoral by research bursary) for funding the project.

\section{Conflicts of interest:}

The authors declare that they have no conflict of interest. 


\section{References}

Acocks, J.P.H., 1988. Veld types of South Africa. In: Memoirs of the Botanical Survey of South Africa. (3rd ed.). Botanical Research Institute, Pretoria, South Africa.

Anonymous, 2015. Achieve Low Pre-Weaning Mortality. Retrieved May 23, 2015, from http://www.thepigsite.com/pighealth/article/216/achieve-low-preweaning-mortality.

Boettiger, H.N., 2000. Challenges facing pig farmers. South African Animal Science (now: Applied Animal Husbandry \& Rural Development), 1(1), 28-31. Retrieved May 23, 2015, from www.sasas.co.za/sites/sasas.co.za/files/Boettiger00AAHRDVol1.pdf.

Carter, N., Dewey, C., Mutua, F., de Lange, C. and Grace, D., 2013. Average daily gain of local pigs on rural and peri-urban smallholder farms in two districts of Western Kenya. Tropical animal health and production, 45,1533-1538. DOI 10.1007/s11250-013-03952

Chittavong, M., Lindberg, J.E. and Jansson, A., 2012.Feeding regime and management of local Lao pigs in Central Lao PDR. Tropical animal health and production, 45, 149 155

Cross, C. and Hornby D., 2002. Opportunities and obstacles to women's land accessing South Africa. A research report for the Promoting Women's Access to Land Programme, 2002. Retrieved March 06, 2015, from file:///C:/Users/User/Downloads/landgender.pdf/.

Department of Agriculture, Forestry and Fisheries (DAFF), 2012a.A profile of the South African pork market value chain. Retrieved April 12, 2015, from http://www.nda.agric.za/docs/AMCP/Pork2012.pdf/. 
Department of Agriculture, Forestry and Fisheries (DAFF), 2012b. Veterinary Procedural Notice For Foot And Mouth Disease Control In South Africa. Retrieved April 21, 2015, from http://www.nda.agric.za/vetweb/Disease\%20Control/Protocols/FMD\%20Veterinary\%2 0Procedural\%20Notice\%20-\%20Approved\%202012\%2006\%2008.pdf/.

Engelbrecht, A., Kirkman, K. and Swanepoel, A., 2004.Veld and Pasture Management Guidelines for Sustainable Animal Production on the Mpumalanga Highveld. (Department of Agriculture, Pretoria, South Africa. 125p).

Kalabamu, F., 2006. Patriarchy and women's land rights in Botswana. Land Use Policy, 23, $237-246$.

Kambashi, B., Picron, P., Boudry, C., Théwis, A., Kiatoko, H. and Bindelle, J., 2014. Smallholder pig production systems along a peri-urban-rural gradient in the Western provinces of the Democratic Republic of the Congo. Journal of Agriculture and Rural Development in the Tropics and Subtropics, 115, 9 -22.

Li, Y., Johnston, L. \& Hilbrands, A., 2010. Pre-weaning mortality of piglets in a bedded group-farrowing system. Journal of Swine Health and Production, 18, 75-80.

Madzimure, J., Chimonyo, M., Zander, K.K. and Dzama, K., 2013. Potential for using indigenous pigs in subsistence-oriented and market-oriented small-scale farming systems of Southern Africa.Tropical animal health and production, 45,135-142.

McCosker, L., 2014. A Review: The pattern of mortality in piglets (birth to 2 months of age) and means to reduce the mortality rate. Retrieved April 12, 2015, from http://www.australianpigfarmers.com.au/Resources/Documents/Piglet\%20Mortality\%2 OReview.pdf. 
Mokoele, J.M., Spencer, B.T., van Leengoed, L.A.M.G. and Fasina, F.O., 2014. Efficiency indices and indicators of poor performance among emerging small-scale pig farmers in the Limpopo Province, South Africa. Onderstepoort Journal of Veterinary Research, 81(1), Art.\#774, 12 pages. http://dx.doi.org/10.4102/ojvr.v81i1.774

Moreki, J.C. and Mphinyane, G.H., 2011.Opportunities and challenges of pig production in Botswana. Livestock Research for Rural Development, 23, 4. Retrieved May 26, 2015 , from http://www.lrrd.org/lrrd23/4/more23087.htm

National Animal Health Monitoring System (NAHMS), 2000. Retrieved May 23, 2015, from http://www.aphis.usda.gov/vs/ceah/cahm/Swine/swine.htm.

Njuki, J., Pali, P., Mburu, S. and Poole, J., 2010. Pig Production, Management and Marketing in the North East Indian State of Nagaland. International Livestock Research Institute Nairobi, Kenya. Retrieved May 23, 2015, from https://cgspace.cgiar.org/bitstream/handle/10568/29056/elks_nagaland.pdf?sequence=1.

Nsoso, S. J., Mannathoko, G. G. and Modise, K., 2006. Monitoring production, health and marketing of indigenous Tswana pigs in Ramotswavillage of Botswana. Livestock Research for Rural Development 18, 125. Retrieved May 23, 2015, from http://www.lrrd.org/lrrd18/9/nsos18125.htm

Oladele, O.I., Kolawole, A.E. and Antwi, M.A., 2013.Knowledge of biosecurity among livestock farmers along border villages of South Africa and Botswana. Asian Journal of Animal and Veterinary Advances, 8(7), 874-884. doi: 10.3923/ajava.2013.

Otte, M.J., Nugent, R. and McLeod, A., 2004.Transboundary Animal Diseases.Assessment of Socio-economic Impacts and Institutional Responses.Livestock policy discussion, FAO, 9. Retrieved May 23, 2015, from http://www.fao.org/3/a-ag273e.pdf. 
Statistical South Africa (STATSA), 2013. Mpumalanga Population in: Mid-Year Population Estimates, Report 0302. Retrieved May 21, 2015, from http://www.statssa.gov.za/publications/P0302/P03022013.pdf/.

The Scientific Panel for Animal Health and Welfare (SP-AHAW) of the European Food Safety Authority, 2007. Scientific Opinion of the Panel on Animal Health and Welfare on a request from the Commission on Animal health and welfare aspects of different housing and husbandry systems for adult breeding boars, pregnant, farrowing sows and unweaned piglets. The EFSA Journal, 572, 1-13. 


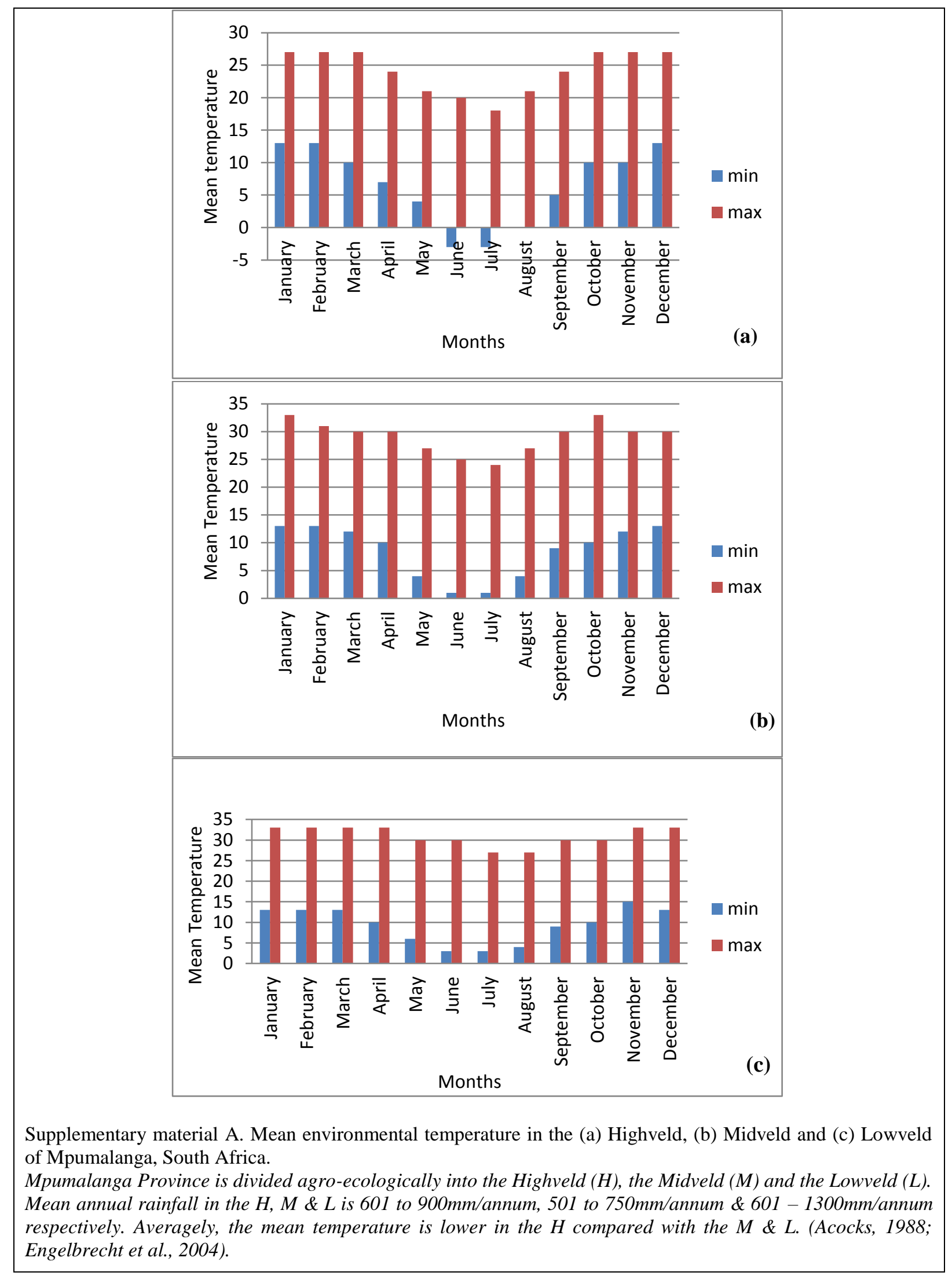


Supplementary material B: Farmers-related variables among the survey small-scale pig farmers,

Mpumalanga $(\mathrm{n}=220)$

\begin{tabular}{|c|c|c|c|c|c|c|}
\hline Variables & Descriptors & $\begin{array}{c}\text { Highveld } \\
(\mathbf{n}=127) \\
(\%)\end{array}$ & $\begin{array}{c}\text { Lowveld } \\
(n=37)(\%)\end{array}$ & $\begin{array}{c}\text { Midveld } \\
(\mathrm{n}=56)(\%)\end{array}$ & $\begin{array}{l}\text { Mpumalanga }(\mathbf{n}= \\
\text { 220) \% }\left(\mathbf{C I} \mathbf{I}_{95 \%}\right)\end{array}$ & P-value \\
\hline \multirow[t]{2}{*}{ Gender } & Male & $\begin{array}{l}73.2(65.4 \\
81.0)\end{array}$ & $\begin{array}{l}43.2(26.5 \\
\quad 60.0)\end{array}$ & $\begin{array}{l}55.4(41.9 ; \\
\quad 68.8)\end{array}$ & $63.6(57.2 ; 70.0)$ & $<0.0001$ \\
\hline & Female & $\begin{array}{l}26.8(19.0 \\
34.6)\end{array}$ & $\begin{array}{l}56.8(40.0 \\
73.5)\end{array}$ & $\begin{array}{l}44.6(31.2 \\
58.1)\end{array}$ & $36.4(30.0 ; 42.8)$ & \\
\hline \multirow[t]{5}{*}{ Age } & $<20$ years & $\begin{array}{c}1.6(-0.62 \\
3.77)\end{array}$ & 0 & 0 & $0.9(-0.4 ; 2.2)$ & $<0.01$ \\
\hline & $21-30$ years & $\begin{array}{l}5.5(1.5 \\
9.5)\end{array}$ & $\begin{array}{c}5.4(-0.2 \\
13.0)\end{array}$ & $12.5(3.6 ; 21.4)$ & $7.3(3.8 ; 10.7)$ & \\
\hline & $31-40$ years & $\begin{array}{c}14.2(8.0 \\
20.3)\end{array}$ & $\begin{array}{c}16.2(3.8 \\
28.7)\end{array}$ & $8.9(1.2 ; 16.6)$ & $13.2(8.7 ; 17.7)$ & \\
\hline & $41-50$ years & $\begin{array}{l}20.5(13.4 ; \\
27.6)\end{array}$ & $\begin{array}{l}35.1(19.0 \\
51.3)\end{array}$ & $\begin{array}{c}26.8(14.8 \\
38.8)\end{array}$ & $24.6(18.8 ; 30.3)$ & \\
\hline & $>50$ years & $\begin{array}{c}58.3(49.6 \\
70.0)\end{array}$ & $\begin{array}{l}43.2(26.5 \\
60.0)\end{array}$ & $\begin{array}{l}51.8(38.3 ; \\
65.3)\end{array}$ & $54.1(47.5 ; 60.7)$ & \\
\hline \multirow[t]{3}{*}{ Race } & Black & $\begin{array}{l}97.6(95.0 \\
100)\end{array}$ & 100.0 & 100.0 & $98.6(97.1 ; 100.2)$ & $<0.0001$ \\
\hline & Coloured & $\begin{array}{l}0.8(-0.77 \\
2.3)\end{array}$ & 0 & 0 & $0.5(-0.4 ; 0.1)$ & \\
\hline & White & $\begin{array}{c}1.57(-0.6 \\
3.8)\end{array}$ & 0 & 0 & $0.9(-0.4 ; 21.7)$ & \\
\hline \multirow[t]{4}{*}{ Economic status } & Poor & $\begin{array}{l}48.0(39.2 \\
56.8)\end{array}$ & $\begin{array}{l}59.5(42.9 ; \\
76.1)\end{array}$ & $\begin{array}{c}60.7(47.5 \\
73.9)\end{array}$ & $53.2(46.5 ; 59.8)$ & $<0.01$ \\
\hline & $\begin{array}{l}\text { Just below } \\
\text { average }\end{array}$ & $\begin{array}{l}25.2(17.5 \\
32.9)\end{array}$ & $\begin{array}{c}18.9(5.7 \\
32.2)\end{array}$ & $\begin{array}{c}28.6(16.4 \\
40.8)\end{array}$ & $25.0(19.2 ; 30.8)$ & \\
\hline & Average & $\begin{array}{l}25.2(17.5 ; \\
32.9)\end{array}$ & $\begin{array}{l}21.6(7.7 \\
35.5)\end{array}$ & $10.7(2.4 ; 19.1)$ & $20.9(15.5 ; 26.3)$ & \\
\hline & $\begin{array}{l}\text { Above } \\
\text { average }\end{array}$ & $\begin{array}{c}1.6(-0.6 \\
3.8)\end{array}$ & 0 & 0 & $0.9(-0.4 ; 2.2)$ & \\
\hline \multirow[t]{4}{*}{$\begin{array}{l}\text { Educational } \\
\text { qualification }\end{array}$} & $\begin{array}{l}\text { No formal } \\
\text { schooling }\end{array}$ & $\begin{array}{c}18.1(11.3 ; \\
24.9)\end{array}$ & $\begin{array}{l}13.5(2.0 \\
25.1)\end{array}$ & $\begin{array}{l}21.4(10.3 ; \\
32.5)\end{array}$ & $18.2(13.1 ; 23.3)$ & $<0.01$ \\
\hline & Grade 1-11 & $\begin{array}{l}52.8(44.0 \\
\quad 61.6)\end{array}$ & $\begin{array}{l}56.8(40.0 \\
73.5)\end{array}$ & $\begin{array}{c}55.4(41.9 \\
68.8)\end{array}$ & $54.1(47.5 ; 60.7)$ & \\
\hline & Grade 12 & $\begin{array}{l}22.1(14.7 \\
29.4)\end{array}$ & $\begin{array}{c}16.2(3.8 \\
28.7)\end{array}$ & $10.7(2.4 ; 19.1)$ & $18.2(13.1 ; 23.3)$ & \\
\hline & Post-matric & $\begin{array}{c}7.1(2.6 \\
11.6)\end{array}$ & $\begin{array}{c}13.5(2.0 \\
25.1)\end{array}$ & $1.3(3.6 ; 21.4)$ & $9.6(5.6 ; 13.5)$ & \\
\hline \multirow[t]{3}{*}{ Location } & Rural & $\begin{array}{c}46.5(37.7 \\
55.2)\end{array}$ & $\begin{array}{c}91.9(82.7 \\
101.1)\end{array}$ & $\begin{array}{c}87.5(78.6 \\
96.4)\end{array}$ & $64.6(58.2 ; 70.9)$ & $<0.01$ \\
\hline & Urban & $\begin{array}{l}3.9(0.5 \\
7.4)\end{array}$ & 0 & $1.8(-1.8 ; 5.4)$ & $2.7(0.6 ; 4.9)$ & \\
\hline & Peri-urban & $\begin{array}{l}49.6(40.8 \\
58.4)\end{array}$ & $\begin{array}{c}8.1(-1.1 \\
17.3)\end{array}$ & $10.7(2.4 ; 19.1)$ & $32.7(26.5 ; 39.0)$ & \\
\hline \multirow[t]{5}{*}{ Household size } & 1 & $\begin{array}{c}1.6(-0.6 \\
3.8)\end{array}$ & 0 & $1.8(-1.8 ; 5.4)$ & $1.4(-0.2 ; 2.9)$ & $<0.01$ \\
\hline & 2 & $\begin{array}{c}9.5(4.3 \\
14.6)\end{array}$ & $\begin{array}{c}8.1(-1.1 \\
17.3)\end{array}$ & $5.4(-0.7 ; 11.4)$ & $8.2(4.5 ; 11.8)$ & \\
\hline & $3-5$ & $\begin{array}{c}44.9(36.1 ; \\
53.7)\end{array}$ & $\begin{array}{c}37.8(21.4 \\
54.2)\end{array}$ & $\begin{array}{l}32.1(19.5 \\
\quad 44.8)\end{array}$ & $40.5(33.9 ; 47.0)$ & \\
\hline & $6-8$ & $\begin{array}{c}37.0(28.5 \\
45.5)\end{array}$ & $\begin{array}{c}40.5(23.9 \\
57.1)\end{array}$ & $\begin{array}{c}48.2(34.7 \\
61.7)\end{array}$ & $40.5(33.9 ; 47.0)$ & \\
\hline & $>8$ & $\begin{array}{c}7.1(2.3 \\
11.6)\end{array}$ & $\begin{array}{l}13.5(2.0 \\
25.1)\end{array}$ & $12.5(3.6 ; 21.4)$ & $9.6(5.6 ; 13.5)$ & \\
\hline \multirow{2}{*}{$\begin{array}{l}\text { Received } \\
\text { agricultural } \\
\text { training }\end{array}$} & No & $\begin{array}{l}77.8(70.4 \\
85.1)\end{array}$ & $\begin{array}{c}78.4(64.5 \\
92.3)\end{array}$ & $\begin{array}{c}87.5(78.6 \\
96.4)\end{array}$ & $80.4(75.1 ; 85.7)$ & $<0.0001$ \\
\hline & Yes & $\begin{array}{c}22.2(14.9 ; \\
29.6)\end{array}$ & $\begin{array}{c}21.6(7.7 \\
35.5)\end{array}$ & $12.5(3.6 ; 21.4)$ & $19.6(14.3 ; 24.9)$ & \\
\hline \multirow{2}{*}{$\begin{array}{l}\text { Received } \\
\text { financial } \\
\text { assistance/inputs }\end{array}$} & No & $\begin{array}{c}67.5(59.2 ; \\
75.8)\end{array}$ & $\begin{array}{c}73.0(58.0 \\
89.0)\end{array}$ & $\begin{array}{c}62.5(49.4 \\
75.6)\end{array}$ & $67.1(60.9 ; 73.4)$ & $<0.0001$ \\
\hline & Yes & $\begin{array}{c}32.5(24.2 ; \\
40.8)\end{array}$ & $\begin{array}{c}27.0(12.0 \\
42.0)\end{array}$ & $\begin{array}{c}37.5(24.4 \\
50.6)\end{array}$ & $32.9(26.6 ; 39.2)$ & \\
\hline
\end{tabular}

Significant differences existed between or among the descriptors in each variables analysed. 
Supplementary material C: Herd-related variables among the survey small-scale pig farmers,

Mpumalanga $(\mathrm{n}=220)$

\begin{tabular}{|c|c|c|c|c|c|c|}
\hline Variables & Descriptors & $\begin{array}{c}\text { Highveld } \\
(\mathbf{n}=127)(\%)\end{array}$ & $\begin{array}{c}\text { Lowveld } \\
(\mathbf{n}=37)(\%)\end{array}$ & $\begin{array}{c}\text { Midveld } \\
(n=56)(\%)\end{array}$ & $\begin{array}{c}\text { Mpumalanga(\%) } \\
\text { CI }_{95 \%}\end{array}$ & P-value \\
\hline \multirow{3}{*}{$\begin{array}{l}\text { Type of } \\
\text { breed kept }\end{array}$} & Kolbroek & $4.7(1.0 ; 8.5)$ & 0 & $7.1(0.2 ; 14.1)$ & $4.6(1.8 ; 7.3)$ & $<0.01$ \\
\hline & Exotic and their crosses & $\begin{array}{l}86.6(80.6 \\
92.6)\end{array}$ & $\begin{array}{l}94.6(87.0 \\
102.3)\end{array}$ & $\begin{array}{l}91.1(83.4 ; \\
98.8)\end{array}$ & $89.1(84.9 ; 93.2)$ & \\
\hline & Mix of Kolbroek and exotic & $8.7(3.7 ; 13.6)$ & $\begin{array}{l}5.4(-2.2 \\
13.0)\end{array}$ & $1.8(-1.8 ; 5.4)$ & $6.1(3.1 ; 9.6)$ & \\
\hline \multirow{4}{*}{$\begin{array}{l}\text { No of sow in } \\
\text { the herd }\end{array}$} & No breeding & $1.6(-0.6 ; 3.8)$ & 0 & 0 & $0.9(-0.4 ; 2.2)$ & $<0.01$ \\
\hline & $1-10$ sows & $\begin{array}{l}85.8(79.7 \\
92.0)\end{array}$ & $\begin{array}{l}81.1(67.8 ; \\
94.3)\end{array}$ & $\begin{array}{l}94.6(88.6 \\
100.7)\end{array}$ & $87.3(82.8 ; 91.7)$ & \\
\hline & $11-20$ sows & $7.9(3.1 ; 12.6)$ & $\begin{array}{l}8.1(-1.1 \\
17.3)\end{array}$ & $3.6(-1.4 ; 8.6)$ & $6.8(3.5 ; 10.2)$ & \\
\hline & $>20$ sows & $4.7(1.0 ; 8.5)$ & $\begin{array}{l}10.8(0.3 ; \\
21.3)\end{array}$ & $1.8(-1.8 ; 5.4)$ & $5(2.1 ; 7.9)$ & \\
\hline \multirow[t]{5}{*}{ Boar source } & Auction & $11.8(6.1 ; 17.5)$ & 2.7 & $8.9(1.2 ; 16.6)$ & $9.6(5.6 ; 13.5)$ & $<0.01$ \\
\hline & $\begin{array}{l}\text { Buy young and raise, select } \\
\text { from own boar }\end{array}$ & $15.0(8.7 ; 21.2)$ & $\begin{array}{l}10.8(-2.8 \\
8.2)\end{array}$ & $\begin{array}{l}10.7(2.4 \\
19.1)\end{array}$ & $13.2(8.7 ; 17.7)$ & \\
\hline & Free range & 0 & $5.4(0.3 ; 21.3)$ & $1.8(-1.8 ; 5.4)$ & $1.4(-0.2 ; 2.9)$ & \\
\hline & Local project breeder & $\begin{array}{l}16.5(10.0 \\
23.1)\end{array}$ & $\begin{array}{l}27.0(12.0 \\
42.0)\end{array}$ & $\begin{array}{l}10.7(2.4 \\
19.1)\end{array}$ & $16.8(11.8 ; 21.8)$ & \\
\hline & Neighbor, relative, mixed & $\begin{array}{l}56.6(48.0 \\
65.4)\end{array}$ & $\begin{array}{l}54.1(37.2 \\
70.9)\end{array}$ & $\begin{array}{l}67.9(55.2 \\
80.5)\end{array}$ & $59.1(52.5 ; 65.6)$ & \\
\hline \multirow{8}{*}{$\begin{array}{l}\text { Boar and } \\
\text { sow stay } \\
\text { together } \\
\text { regularly } \\
\text { Boar length } \\
\text { of stay with } \\
\text { sow during } \\
\text { mating }\end{array}$} & No & $\begin{array}{l}57.6(48.8 \\
66.4)\end{array}$ & $\begin{array}{l}81.1(67.8 \\
94.3)\end{array}$ & $\begin{array}{l}53.6(40.1 \\
67.0)\end{array}$ & $60.6(54.0 ; 67.1)$ & $<0.0001$ \\
\hline & Yes & $\begin{array}{l}42.4(33.6 \\
51.2)\end{array}$ & $\begin{array}{l}18.9(5.7 \\
32.2)\end{array}$ & $\begin{array}{l}46.4(33.0 \\
60.0)\end{array}$ & $39.5(32.9 ; 46.0)$ & \\
\hline & $1-3$ days & $14.8(8.4 ; 21.1)$ & $\begin{array}{l}18.9(5.7 \\
32.2)\end{array}$ & $7.3(0.2 ; 14.4)$ & $13.6(8.9 ; 18.2)$ & $<0.0001$ \\
\hline & 1 week -1 month & $\begin{array}{l}32.0(23.6 \\
40.4)\end{array}$ & $\begin{array}{l}18.9(5.7 \\
32.2)\end{array}$ & $\begin{array}{l}32.7(20.0 \\
45.5)\end{array}$ & $29.9(23.7 ; 36.1)$ & \\
\hline & 2 months -3 months & $2.5(-0.3 ; 5.2)$ & 0 & $1.8(-1.8 ; 5.5)$ & $1.9(0.4 ; 3.7)$ & \\
\hline & Continuous & $\begin{array}{l}40.2(31.3 \\
49.0)\end{array}$ & $\begin{array}{l}16.2(3.8 \\
28.7)\end{array}$ & $\begin{array}{l}54.6(41.0 \\
68.1)\end{array}$ & $39.7(33.1 ; 46.3)$ & \\
\hline & Free range & $9.8(4.5 ; 15.2)$ & $\begin{array}{l}46.0(29.1 ; \\
62.8)\end{array}$ & $3.6(-1.5 ; 8.7)$ & $14.5(9.7 ; 19.2)$ & \\
\hline & Artificial insemination & $0.8(-0.8 ; 2.4)$ & 0 & 0 & $0.5(0.5 ; 1.4)$ & \\
\hline \multirow[t]{3}{*}{ Housing type } & Intensive & $\begin{array}{l}20.6(13.5 \\
27.8)\end{array}$ & $\begin{array}{l}8.1(-1.1 \\
17.3)\end{array}$ & $\begin{array}{l}19.6(8.9 \\
30.4)\end{array}$ & $18.3(13.1 ; 23.4)$ & $<0.01$ \\
\hline & Semi-intensive & $\begin{array}{l}57.9(49.2 \\
66.7)\end{array}$ & $\begin{array}{l}48.7(31.8 \\
65.5)\end{array}$ & $\begin{array}{l}58.93(45.6 \\
72.2)\end{array}$ & $56.6(50.0 ; 63.2)$ & \\
\hline & Free range & $\begin{array}{l}21.4(14.2 \\
28.7)\end{array}$ & $\begin{array}{l}43.2(26.5 \\
60.0)\end{array}$ & $\begin{array}{l}21.43(10.3 \\
32.5)\end{array}$ & $25.1(19.3 ; 30.9)$ & \\
\hline \multirow{5}{*}{$\begin{array}{l}\text { Number of } \\
\text { feeding per } \\
\text { day }\end{array}$} & Nil & 0 & 0 & $1.8(-1.8 ; 5.5)$ & $0.5(-0.5 ; 1.4)$ & $<0.01$ \\
\hline & Once & $\begin{array}{l}28.8(20.8 \\
36.8)\end{array}$ & $\begin{array}{l}29.7(14.3 ; \\
45.2)\end{array}$ & $20(9.1 ; 30.9)$ & $26.7(20.9 ; 32.6)$ & \\
\hline & Twice & $64(55.5 ; 72.5)$ & $\begin{array}{l}64.9(48.7 \\
81.0)\end{array}$ & $\begin{array}{l}72.7(60.6 \\
84.9)\end{array}$ & $66.4(60.0 ; 72.7)$ & \\
\hline & Thrice & $6.4(2.0 ; 10.8)$ & $\begin{array}{l}5.4(-2.2 \\
13.0)\end{array}$ & $\begin{array}{l}5.5(-0.7 \\
11.7)\end{array}$ & $6.0(2.8 ; 9.2)$ & \\
\hline & Ad lib & $0.8(-0.8 ; 2.4)$ & 0 & 0 & $0.45(-0.45 ; 1.4)$ & \\
\hline \multirow{9}{*}{$\begin{array}{l}\text { Implement } \\
\text { vaccination } \\
\text { Record } \\
\text { keeping } \\
\text { Number of } \\
\text { farrowing } \\
\text { per year } \\
\text { Weighing } \\
\text { done before } \\
\text { sale }\end{array}$} & No & 80 & 86.49 & 87.5 & $83.0(78.0 ; 88.05)$ & $<0.0001$ \\
\hline & Yes & 20 & 13.51 & 12.5 & $17.0(12.0 ; 22.1)$ & \\
\hline & No & 89.68 & 94.59 & 89.09 & $90.4(86.4 ; 94.3)$ & $<0.0001$ \\
\hline & Yes & 10.32 & 5.41 & 10.91 & $9.6(5.7 ; 13.6)$ & \\
\hline & 1 & 13.71 & 8.11 & 12.5 & $12.4(8.0 ; 16.9)$ & $<0.01$ \\
\hline & 2 & 79.03 & 81.08 & 76.79 & $78.8(73.3 ; 84.3)$ & \\
\hline & Sometimes 3 & 7.26 & 10.81 & 10.71 & $8.76(4.97 ; 12.55)$ & \\
\hline & No & 94.4 & 100 & 96.43 & $\begin{array}{l}95.87(93.32 \\
98.53)\end{array}$ & $<0.0001$ \\
\hline & Yes & 5.6 & 0 & 3.57 & $4.13(1.47 ; 6.79)$ & \\
\hline
\end{tabular}

